\title{
TITLE:
}

\section{RECK modulates Notch signaling during cortical neurogenesis by regulating ADAM10 activity(Abstract_要旨 )}

\section{AUTHOR(S):}

Muraguchi, Teruyuki

\section{CITATION:}

Muraguchi, Teruyuki. RECK modulates Notch signaling during cortical neurogenesis by regulating ADAM10 activity. 京都大学, 2007, 博士(医学)

ISSUE DATE:

2007-07-23

URL:

http://hdl.handle.net/2433/135770

RIGHT: 


\begin{tabular}{|c|c|}
\hline 名 & 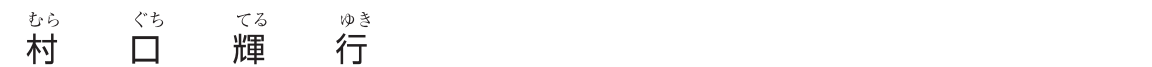 \\
\hline 学位 (専攻分野) & 博 士（医学） \\
\hline 学 位 記 番 号 & 医 博 第 3150 号 \\
\hline 学位授与の日付 & 平成 19 年 7 月 23 日 \\
\hline 学位授与の要件 & 学 位規則第 4 条第 1 項該当 \\
\hline 研究科 · 専攻 & 医学研究科分子医学系専攻 \\
\hline 学位論文題目 & $\begin{array}{l}\text { RECK modulates Notch signaling during cortical neurogenesis by } \\
\text { regulating ADAM10 activity } \\
\text { (RECK は大脳皮質神経発生において ADAM10 活性を制御することにより } \\
\text { Notch シグナルを調節する) }\end{array}$ \\
\hline
\end{tabular}

論文内容 の 要旨

胎生期の神経幹細胞は、神経管を構成する神経上皮に存在し、未分化性を維持しながら自己複製を繰り返し、胎生時期に 応じて神経細胞やグリア細胞に分化する。このため、神経幹細胞は中枢神経・大脳組織を形成するための起源として考えら れているが、その詳細な維持機構は明らかにされていない。Notch は細胞膜貫通型分子であり、そのリガンドである Delta などとの結合により活性化され、標的遺伝子の発現を活性化する。この Notch シグナルは、神経幹細胞だけでなく広汎な幹 細胞の未分化性維持機構に貢献していることが、種を超えて保存されている普遍的機構であるが、細胞外において Notch と Delta の相互作用を調節するメカニズムの詳細は明らかにされていない。また、Notch と Delta は細胞外領域をメタロプロ テアーゼの一種である a disintegrin and metalloproteinase（ADAM）17 およびADAM10によりそれぞれ切断されること が知られているが、その詳細な活性制御機構は不明である。

当研究室において同定された reversion-inducing cysteine-rich protein with Kazal motifs (RECK) は細胞膜上に glycosylphosphatidylinositol アンカーされる糖タンパク質であり、いくつかのメタロプロテアーゼ[matrix metalloproteinase（MMP）2、MMP9、membrane type 1 MMP、CD13/aminopeptidase N]制御する働きをすつことが 示されている。 $R E C K$ 遺伝子久損マウスは、胎生 10.5 日で致死性を示し、これ以前に、細胞外基質形成異常、血管新生や 神経管形成の異常を呈する。胎生期の野生型マウス中枢神経系における $R E C K$ の発現部位は、神経幹・前駆細胞とされる Nestin 陽性細胞と一致する。そこで、 $R E C K$ 欠損マウスの中枢神経系の発生を詳細に解析したところ、神経幹・前駆細胞 の早熟分化が起こっており、これに符合して、神経幹細胞数の著しい減少が観察された。これらの表現型は Notch シグナ ルを構成する遺伝子群が欠損した場合の表現型と酷似しており、実際に RECK 欠損マウスでは活性化 Notch の減少が観察 された。RECK 欠損マウスから採取し、培養した神経幹細胞に恒常的活性化型 Notch をレトロウイルスで導入した場合、ま た培養液中にメタロプロテアーゼ ADAM10 の阻害剂を加えた場合に、その幹細胞能が回復した。また、野生型マウス由来 の神経幹細胞を培養し、RECK の発現を shRNAにより抑制すると、神経分化の促進ならびに Notch リガンドである Delta の ADAM10 依存的な切断の妄進が認められた。このような表現型は、恒常的活性化型 Notch ならびに ADAM10 shRNA の 導入によって回復した。同様に、胎仔脳室内に RECK shRNA を子宮内電気穿孔法を用いて導入すると、導入された神経幹 細胞の多くが神経に分化しており、同時に ADAM10 shRNA を導入した際にはこのような神経分化促進はみられなかった。 さらに、精製したRECK、ADAM10、Delta を用いた生化学的実験により、RECK が直接 ADAM10 の Delta 切断活性を抑 えることが判明した。これらの知見により、RECK が ADAM10 の生理的阻害因子であること、Notch シグナルの上流に存 在する制御因子であること、そして大脳・中枢神経発生の重要な制御因子であることが示された。

\section{論 文 審 査 の 結 果 の 要 旨}

RECK 欠損マウスは、胎生 10.5 日前後で死亡するが、RECK の発生扔ける役割については不明の点が多い。申請者らは、 
胎生期中枢神経系発生における RECK の役割を解析し、以下の知見を得た：

1) $R E C K$ 欠損マウス 10 日肧の中枢神経系において、神経前駆細胞の早熟分化、幹細胞マーカーnestin の減弱、活性化 Notch の滅少が見られた。

2）培養系抢よびマウス個体に扔いて、RECK shRNA は、野生型神経前駆細胞の早熟分化を誘導し、この表現型は、活性化 型 Notch やADAM10 shRNA の導入により抑制された。

3）RECK shRNA は、Notch リガンド Delta の切断充進を誘導した。また、この切断は内在性 ADAM10 に依存していた。 4）組換体 RECK、ADAM10、Delta タンパク質を用いた試験管内実験に扔いて、RECK は、ADAM10による Delta 切断 を直接阻害した。

5）RECK は、Notch リガンドと共に発現させると、細胞間 Notch シグナル伝達を促進した。

これらの結果は、RECK が ADAM10 による Delta 切断を抑制し、Notch の活性化を可能にすること、また、この機構が 中枢神経系発生に必須であることを示唆する。

以上の研究は、Notch シグナル伝達系の新たな制御機構を明らかにしたものであり、分子医学の進歩に寄与するところが 多い。

したがって、本論文は博士（医学）の学位論文として価値あるあのと認める。

な㧍、本学位授与申請者は、平成 19 年 7 月 4 日実施の論文内容とそれに関連した試問を受け、合格と認められたもので ある。 